\title{
Pyrite oxidization accelerates bacterial carbon sequestration in copper mine tailings
}

\author{
Yang $\mathrm{Li}^{1,2}$, Zhaojun $\mathrm{Wu}^{1}$, Xingchen Dong ${ }^{3}$, Zifu Xu ${ }^{1}$, Qixin Zhang ${ }^{1}$, Haiyan Su${ }^{1}$, Zhongjun Jia ${ }^{2}$, and Qingye Sun ${ }^{1}$ \\ ${ }^{1}$ School of Resources and Environmental Engineering, Anhui University, Hefei, Anhui Province, China \\ ${ }^{2}$ State Key Laboratory of Soil and Sustainable Agriculture, Institute of Soil Science, Chinese Academy of Sciences, \\ Nanjing, Jiangsu Province, China \\ ${ }^{3}$ College of Resources and Environmental Sciences, Gansu Agricultural University, Lanzhou, Gansu Province, China
}

Correspondence: Qingye Sun (sunqingye@ahu.edu.cn)

Received: 3 August 2018 - Discussion started: 29 August 2018

Revised: 21 January 2019 - Accepted: 24 January 2019 - Published: 1 February 2019

\begin{abstract}
Polymetallic mine tailings have great potential as carbon sequestration tools to stabilize atmospheric $\mathrm{CO}_{2}$ concentrations. However, previous studies focused on carbonate mineral precipitation, whereas the role of autotrophic bacteria in mine tailing carbon sequestration has been neglected. In this study, carbon sequestration in two samples of mine tailings treated with $\mathrm{FeS}_{2}$ was evaluated using ${ }^{13} \mathrm{C}$ isotope, pyrosequencing and DNA-based stable isotope probing (SIP) analyses to identify carbon fixers. Mine tailings treated with $\mathrm{FeS}_{2}$ exhibited a higher percentage of ${ }^{13} \mathrm{C}$ atoms $(1.76 \pm 0.06 \%$ for Yangshanchong and $1.36 \pm 0.01 \%$ for Shuimuchong) than did controls over a 14-day incubation, which emphasized the role of autotrophs in carbon sequestration with pyrite addition. Pyrite treatment also led to changes in the composition of bacterial communities, and several autotrophic bacteria increased, including Acidithiobacillus and Sulfobacillus. Furthermore, pyrite addition increased the relative abundance of the dominant genus Sulfobacillus by $8.86 \%$ and $5.99 \%$ in Yangshanchong and Shuimuchong samples, respectively. Furthermore, DNA SIP results indicated a 8.20-16.50 times greater gene copy number for $c b b L$ than $c b b M$ in ${ }^{13} \mathrm{C}$-labeled heavy fractions, and a Sulfobacillus-like $c b b L$ gene sequence (cbbL-OTU1) accounted for $30.11 \%-34.74 \%$ of all $c b b L$ gene sequences in ${ }^{13} \mathrm{C}$-labeled heavy fractions of mine tailings treated with $\mathrm{FeS}_{2}$. These findings highlight the importance of the $c b b L$ gene in bacterial carbon sequestration and demonstrate the ability of chemoautotrophs to sequester carbon during sulfide mineral oxidation in mine tailings. This study is the first
\end{abstract}

to investigate carbon sequestration by autotrophic bacteria in mine tailings through the use of isotope tracers and DNA SIP.

\section{Introduction}

Soil ecosystems have great potential as carbon sinks to stabilize $\mathrm{CO}_{2}$ and regulate climate change (White et al., 2000). Atmospheric $\mathrm{CO}_{2}$ can be fixed in plants via photosynthesis and assimilated into soils via decomposition and microbial activity (Deng et al., 2016; Antonelli et al., 2018), and autotrophic bacteria play a significant role in carbon sequestration in soil ecosystems (Berg, 2011; Alfreider et al., 2017). Six autotrophic carbon sequestration mechanisms are widespread, including the Calvin-Benson-Bassham (CBB) cycle, the reductive tricarboxylic acid (rTCA) cycle, the reductive acetyl-CoA pathway, and the recently discovered 3-hydroxypropionate-4-hydroxybutyrate (HP-HB) cycles (Berg, 2011; Alfreider et al., 2017). Among them, the $\mathrm{CBB}$ cycle is the most prevalent means of $\mathrm{CO}_{2}$ fixation by autotrophs including autotrophic bacteria (Tabita, 1999; Berg, 2011). The enzyme ribulose-1,5-bisphosphate carboxylase/oxygenase ( $\mathrm{RuBisCO}$ ) is important in the $\mathrm{CBB}$ cycle and is in fact the most prominent enzyme on Earth (Raven, 2013). The $c b b L$ and $c b b M$ genes encoding the large subunit of RuBisCO, with $25 \%$ to $30 \%$ amino acid sequence identity (Tabita et al., 2008), serve as autotroph markers (Berg, 2011; Alfreider et al., 2017).

Compared with soil ecosystems, polymetallic mine tailings exhibit specific features, including a lack of organic 
matter, nutrients, and nutrient-holding capacity (Lottermoser, 2010; Young et al., 2015); these characteristics restrict plant growth, and it is generally difficult to restore plant productivity in mining wastelands ( $\mathrm{Li}$ et al., 2017; Hu et al., 2018). As the limited amount of organic matter in mine tailings also inhibits the activities of heterotrophic bacteria, the microbes in these environments are dominated by lithotrophs ( $\mathrm{Li}$ et al., 2015), and these autotrophic bacteria may accordingly play a role in organic carbon sequestration in mine tailings that cannot be ignored. In addition, polymetallic mine tailings have considerable potential to stabilize levels of atmospheric $\mathrm{CO}_{2}$ (Harrison et al., 2013) through the carbonation of noncarbonate minerals, including dissolution of silicates, hydroxides, and oxides and precipitation of carbonate minerals (McCutcheon et al., 2014, 2016; Meyer et al., 2014). However, previous studies have mainly focused on carbonate mineral precipitation, whereas the role of autotrophic bacteria in carbon sequestration by mine tailings has been overlooked.

Polymetallic mine tailings contain sulfide minerals (e.g., pyrite), and oxidation of these sulfide minerals leads to a decrease in $\mathrm{pH}$, also known as mine tailing acidification. Previous studies have noted that due to the limited amount of organic matter present, polymetallic mine tailings have lithotroph-dominated microbial compositions ( $\mathrm{Li}$ et al., 2015). Consequently, acidophilic, chemoautotrophic bacteria, including Acidithiobacillus, Leptospirillum, and Sulfobacillus (Chen et al., 2013; Liu et al., 2014), largely participate in ferrous and sulfur oxidation in mine tailings, and these autotrophic taxa have leading roles in carbon cycling and energy flow during the mine tailing acidification process. Nonetheless, the relationship between the oxidation of sulfide minerals and carbon sequestration by these acidophilic chemoautotrophic bacteria remains unknown. In the present study, we conducted a microcosm experiment using mine tailings collected from two sites to determine the effects of sulfide mineral (pyrite) oxidation on carbon sequestration in mine tailings through pyrite addition. The main carbon fixers were also examined using DNA-based stable isotope probing (DNA SIP) and $c b b L$ and $c b b M$ gene analysis. Our objectives were to investigate whether sulfide mineral oxidation can stimulate carbon sequestration in mine tailings and to identify key carbon sequestration groups in mine tailings during the acidification process.

\section{Materials and methods}

\subsection{Sampling of mine tailings}

Samples of mine tailings were collected from the Tongling Yangshanchong $\left(30^{\circ} 54^{\prime} \mathrm{N}, 117^{\circ} 53^{\prime} \mathrm{E}\right)$ and Shuimuchong $\left(30^{\circ} 55^{\prime} \mathrm{N}, 117^{\circ} 50^{\prime} \mathrm{E}\right)$ mine tailing ponds of copper mines in Anhui Province, east China. Samples of oxidized mine tailings on the surface $(0-20 \mathrm{~cm})$ were collected using a steel corer in October 2015. The mine tailing samples were placed in sterilized plastic bags, transported to the laboratory in an ice cooler, and stored at $-20^{\circ} \mathrm{C}$ before analysis. The properties of the mine tailings were as follows:

- Yangshanchong acidic samples had a pH of 3.21, total nitrogen (TN) of $0.11 \mathrm{~g} \mathrm{~kg}^{-1}$, total organic carbon (TOC) of $16 \mathrm{~g} \mathrm{~kg}^{-1}, \mathrm{SO}_{4}^{2-}$ of $13.32 \mathrm{~g} \mathrm{~kg}^{-1}$, As $\mathrm{s}_{\mathrm{T}}$ of $63.29 \mathrm{mg} \mathrm{kg}^{-1}, \mathrm{Fe}_{\mathrm{T}}$ of $133.46 \mathrm{~g} \mathrm{~kg}^{-1}, \mathrm{Cu}_{\mathrm{T}}$ of $1.95 \mathrm{~g} \mathrm{~kg}^{-1}, \mathrm{~Pb}_{\mathrm{T}}$ of $27.58 \mathrm{mg} \mathrm{kg}^{-1}$, and $\mathrm{Zn}_{\mathrm{T}}$ of $205.44 \mathrm{mg} \mathrm{kg}^{-1}$.

- Shuimuchong acidic samples had a pH of 2.92, TN of $0.11 \mathrm{~g} \mathrm{~kg}^{-1}$, TOC of $18 \mathrm{~g} \mathrm{~kg}^{-1}, \mathrm{SO}_{4}^{2-}$ of $8.84 \mathrm{~g} \mathrm{~kg}^{-1}$, As $\mathrm{T}_{\mathrm{T}}$ of $51.77 \mathrm{mg} \mathrm{kg}^{-1}, \mathrm{Fe}_{\mathrm{T}}$ of $117.59 \mathrm{~g} \mathrm{~kg}^{-1}, \mathrm{Cu}_{\mathrm{T}}$ of $2.53 \mathrm{~g} \mathrm{~kg}^{-1}, \mathrm{~Pb}_{\mathrm{T}}$ of $30.43 \mathrm{mg} \mathrm{kg}^{-1}$, and $\mathrm{Zn}_{\mathrm{T}}$ of $176.59 \mathrm{mg} \mathrm{kg}^{-1}$.

\subsection{DNA SIP microcosms}

A total of four treatments were established using microcosms of the two mine tailings. In the $\mathrm{FeS}_{2}$ treatment, fresh mine tailings (equivalent to $10.0 \mathrm{~g}$ d.w.s., dry weight soil) of each sample were mixed with a total of $2 \mathrm{~g}$ of sterile pulverized $\mathrm{FeS}_{2}$ at approximately $60 \%$ maximum water-holding capacity, followed by incubation at $25^{\circ} \mathrm{C}$ in the dark for 14 days. The microcosms were incubated with $10 \%{ }^{13} \mathrm{C}-\mathrm{CO}_{2}$ or ${ }^{12} \mathrm{C}$ $\mathrm{CO}_{2}$, and both treatments were constructed in triplicate for DNA SIP analysis. Yangshanchong mine (YM) tailing samples and Shuimuchong mine (SM) tailings cultured with $\mathrm{FeS}_{2}$ are abbreviated as $\mathrm{YM}_{-} \mathrm{FeS} \mathrm{S}_{2}$ and $\mathrm{SM}_{-} \mathrm{FeS} \mathrm{S}_{2}$; fresh mine tailings at approximately $60 \%$ maximum water-holding capacity without any additive were used as the control groups and abbreviated as YM_ck and SM_ck.

\subsection{Chemical property analysis}

Carbon isotope composition was analyzed using a Delta V Advantage mass spectrometer (Thermo Fisher Scientific, Inc., USA) coupled with an elemental analyzer (Flash2000; HT Instruments, Inc., USA) in continuous-flow mode. The

${ }^{13} \mathrm{C}$ atom $\%$ was calculated as follows:

${ }^{13} \mathrm{C}$ atom $\%=\frac{\left[{ }^{13} \mathrm{C}\right]}{\left[{ }^{13} \mathrm{C}\right]+\left[{ }^{12} \mathrm{C}\right]} \times 100$.

The TOC content was assessed using an element analyzer (vario MACRO cube, Elementar Inc., Germany). The carbon isotope composition and TOC content were determined after soil acidification pretreatment to remove inorganic carbon, as described previously (Wang et al., 2015). The $\mathrm{pH}$ of the mine tailing samples was measured using a $\mathrm{pH}$ meter (tailings : water $=1 \mathrm{~g}: 5 \mathrm{~mL}$ ) at the end of the microcosm experiment. $\mathrm{Fe}^{2+}$ and $\mathrm{Fe}^{3+}$ in the soils were extracted using $\mathrm{HCl}$. $\mathrm{Fe}^{2+}$ in the extract was measured using a spectrophotometric method after mixing with phenanthroline and trisodium citrate; $\mathrm{Fe}^{3+}$ in the extract was reduced to $\mathrm{Fe}^{2+}$ by hydroxylam- 
monium chloride and measured using the spectrophotometric method (Heron et al., 1994). The total sulfate ion content was determined via ion chromatography after extraction with sodium hydroxide, as described previously (Yin and Catalan, 2003).

\subsection{DNA extraction and SIP gradient fractionation}

Total DNA was extracted from each sample using the FastDNA $^{\circledR}$ SPIN Kit for Soil (MP Biomedicals, Cleveland, $\mathrm{OH}$, USA) according to the manufacturer's instructions. DNA-based stable isotope probing (DNA SIP) fractionation was performed as previously described (Zheng et al., 2014), and 14 gradient fractions were generated for each sample. The refractive index of each fractionated DNA was measured using an AR200 digital handheld refractometer (Reichert, Inc., Buffalo, NY, USA).

\subsection{Real-time quantitative PCR analysis of the $c b b L$ and $c b b M$ genes}

Real-time quantitative polymerase chain reaction (PCR) analysis to determine the copy numbers of the $c b b L, c b b M$, and 16S rRNA genes in DNA gradient fractions from the $\mathrm{YM}_{\text {IFeS }}$ and SM_FeS 2 DNA SIP microcosms was performed using a CFX96 optical real-time detection system (Bio-Rad, Laboratories Inc., Hercules, CA, USA). The K2fV2r primer pair (K2f: $5^{\prime}$-ACC AYC AAG CCS AAG CTS GG-3' and V2r: 5'-GCC TTC SAG CTT GCC SAC CRC$3^{\prime}$ ) (Nanba et al., 2004), the cbbMF-cbbMR primer pair (cbbMF: 5'-TTC TGG CTG GGB GGH GAY TTY ATY AAR AAY GAC GA-3' and cbbM-R: 5'-CCG TGR CCR GCV CGR TGG TAR TG-3') (Campbell and Cary, 2004), and the 515F-907R primer pair (515F: 5'-GTG CCA GCM GCC GCG G-3' and 907R: 5'-CCG TCA ATT CMT TTR AGT TT-3') (Zhou et al., 2011) were used to amplify the $c b b L, c b b M$, and $16 \mathrm{~S}$ rRNA genes, respectively. The reactions were performed in a $20 \mu \mathrm{L}$ mixture containing $10.0 \mu \mathrm{L}$ of SYBR Premix Ex Taq (TaKaRa), each primer at $0.5 \mu \mathrm{M}$, and $1 \mu \mathrm{L}$ of DNA template. qPCR analysis of the $c b b L$, $c b b M$, and 16S rRNA genes was performed under the following conditions: 40 cycles of $30 \mathrm{~s}$ at $95^{\circ} \mathrm{C}, 30 \mathrm{~s}$ at $55^{\circ} \mathrm{C}$ (cbbL and 16S rRNA genes) or $57^{\circ} \mathrm{C}$ ( $c b b M$ gene), and $45 \mathrm{~s}$ at $72{ }^{\circ} \mathrm{C}$. Standard curves were obtained using 10 -fold serial dilutions of linearized recombinant plasmids containing the $c b b L, c b b M$, and 16S rRNA genes with known copy numbers. The amplification efficiencies were 90\%-100\%, with $R^{2}$ values greater than 0.99 .

\subsection{Pyrosequencing of the 16S rRNA gene}

The composition of the bacterial communities in different samples was assessed by $16 \mathrm{~S}$ rRNA gene pyrosequencing. The 16S rRNA gene from the ${ }^{13} \mathrm{C}$-labeled DNA fraction, with $\mathrm{CsCl}$ buoyant densities of $1.738 \mathrm{~g} \mathrm{~mL}^{-1}$ in the heavy fraction of YM_FeS 2 and $1.734 \mathrm{~g} \mathrm{~mL}^{-1}$ in the heavy frac- tion of SM_FeS 2 , was also amplified for pyrosequencing. The primer pair 515F-907R was used for amplification of the V4-V5 regions of the 16S rRNA gene.

Primers were tagged with unique bar codes for each sample. Each sample was amplified in triplicate, and the products were pooled. Negative controls using sterilized water instead of soil DNA extract were included to check for primer or sample DNA contamination. The qualities and concentrations of the purified bar-coded PCR products were determined using a NanoDrop spectrophotometer. The bacterial community composition of each sample was assessed by Illumina MiSeq sequencing of the $16 \mathrm{~S}$ rRNA gene using MiSeq Reagent Kit v3.

Read merging and quality filtering of the raw sequences were performed using QIIME software with the UPARSE pipeline. The "identify_chimeric_seqs.py" command was used to identify chimeric sequences according to the UCHIME algorithm, and chimeric sequences were removed with the "filter_fasta.py" command. Operational taxonomic units (OTUs) were clustered with $97 \%$ similarity, and OTU picking and taxonomy assignments were performed with the "pick_de_novo_otus.py" command for subsequent analysis. OTUs containing less than 10 reads in the ${ }^{13} \mathrm{C}$-labeled DNA fractions were removed. The raw amplicon sequence data for the 16S rRNA gene have been deposited in the GenBank sequence read archive under accession number SRP155504.

\subsection{Clone library construction of the $c b b L$ and $c b b M$ genes}

Clone libraries of the $c b b L$ and $c b b M$ genes were also constructed using ${ }^{13} \mathrm{C}$-labeled DNA fractions with $\mathrm{CsCl}$ buoyant densities of $1.738 \mathrm{~g} \mathrm{~mL}^{-1}$ in the $\mathrm{YM}_{-} \mathrm{FeS}_{2}$ heavy fraction and $1.734 \mathrm{~g} \mathrm{~mL}^{-1}$ in the $\mathrm{SM}_{-} \mathrm{FeS}_{2}$ heavy fraction. Primer pairs K2f-V2r and cbbMF-cbbMR were used to amplify the $c b b L$ and $c b b M$ genes, respectively. Triplicate amplicons were pooled, ligated to the pGEM-T vector (Promega, Fitchburg, WI, USA), and transformed into competent DH5. $\alpha$ cells. Sanger sequencing of randomly selected positive clones reveals $188 \mathrm{cbbL}$ gene sequences and 183 cbbM gene sequences. OTU clustering with $97 \%$ similarity was performed using mothur. Representative OTU sequences of the $c b b L$ and $c b b M$ genes obtained from clone library sequencing have been

deposited in GenBank under accession numbers MH699091 to MH699105.

\subsection{Data analysis}

Bray-Curtis distance matrices for the overall bacterial community composition among the samples were calculated in R v.3.3.2 using the "vegdist" function of the vegan package and visualized by nonmetric multidimensional scaling (NMDS) in Origin 8. A heat map of dominant genera with relative abundances above $0.02 \%$ was applied for plotting 

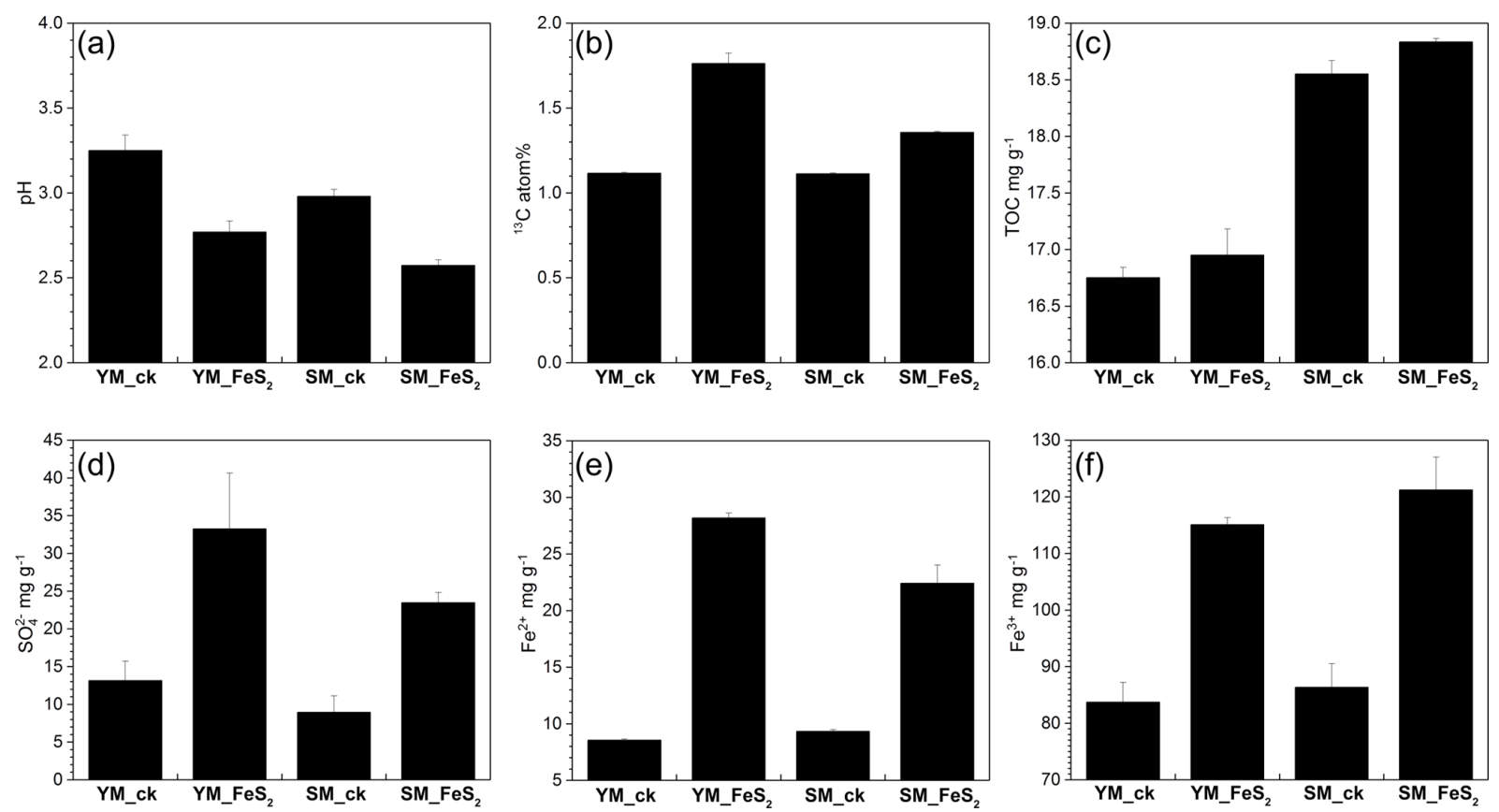

Figure 1. $\mathrm{pH}$ values (a), ${ }^{13} \mathrm{C}$ atom \% (b), and TOC (c), $\mathrm{SO}_{4}^{2-}$ (d), $\mathrm{Fe}^{2+}$ (e), and $\mathrm{Fe}^{3+}$ (f) contents in mine tailings. The error bars indicate the standard errors of three subsamples for each tailing sample. To determine ${ }^{13} \mathrm{C}$ atom $\%(\mathbf{b})$, all analyzed samples were treated with ${ }^{13} \mathrm{C}-\mathrm{CO}_{2}$ in microcosms. YM_ck, control group of Yangshanchong mine tailings; SM_ck, control group of Shuimuchong mine tailings; YM_FeS 2 , Yangshanchong mine tailings treated with $\mathrm{FeS}_{2} ; \mathrm{SM}_{2} \mathrm{FeS}_{2}$, Shuimuchong mine tailings treated with $\mathrm{FeS}_{2}$.

in the $\mathrm{R}$ environment using the pheatmap package. Translated $c b b L$ and $c b b M$ sequences from the heavy fractions were used to construct a phylogenetic tree with the neighborjoining method using the MEGA package, version 7.0.

\section{Results}

\subsection{Pyrite oxidation and carbon sequestration}

No significant changes in chemical properties, $\mathrm{pH}$ values ( $3.25 \pm 0.09$ in YM_ck and $2.98 \pm 0.04$ in SM_ck), sulfate $\left(\mathrm{SO}_{4}^{2-}\right)$ contents $\left(13.15 \pm 2.58 \mathrm{mgg}^{-1}\right.$ in $\mathrm{YM}_{-} \mathrm{ck}$ and $8.95 \pm 2.19 \mathrm{mg} \mathrm{g}^{-1}$ in SM_ck), and TOC contents $(16.75 \pm$ $0.09 \mathrm{mg} \mathrm{g}^{-1}$ in YM_ck and $18.55 \pm 0.12 \mathrm{mg} \mathrm{g}^{-1}$ in SM_ck) were found for the control groups compared to the original Yangshanchong and Shuimuchong acidic samples after 14 days of incubation (Fig. 1). However, the addition of pyrite decreased $\mathrm{pH}$ values in the YM and SM samples by $0.48 \pm 0.16$ and $0.41 \pm 0.07$, respectively. Pyrite addition also increased the $\mathrm{SO}_{4}^{2-}$ content by $252.96 \%$ and $262.35 \%$, $\mathrm{Fe}^{2+}$ content by $329.47 \%$ and $240.38 \%$, and $\mathrm{Fe}^{3+}$ content by $137.47 \%$ and $140.37 \%$ in the YM and SM samples, respectively. Together, these data indicate the occurrence of pyrite oxidization and acidification in mine tailings after pyrite addition. Additionally, the TOC content increased by $0.20 \pm 0.11 \mathrm{mg} \mathrm{g}^{-1}$ in $\mathrm{YM}_{-} \mathrm{FeS}_{2}$ and $0.28 \pm 0.14 \mathrm{mg} \mathrm{g}^{-1}$ in SM_FeS 2 , and the ${ }^{13} \mathrm{C}$ atom $\%$ values in $\mathrm{YM}_{-} \mathrm{FeS}_{2}(1.76 \pm$

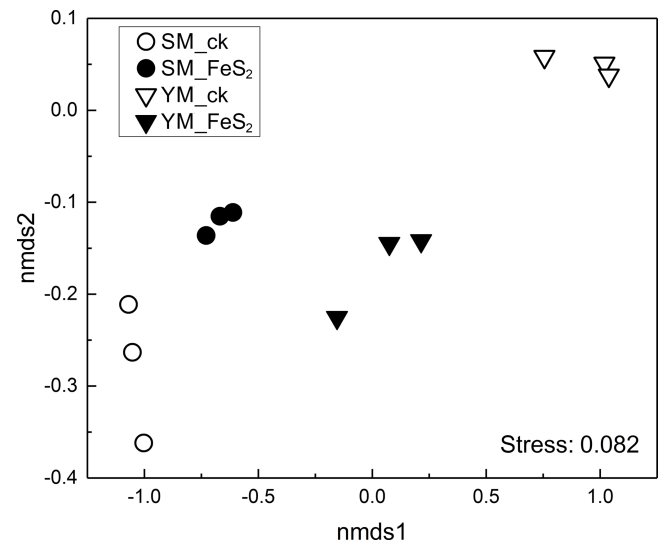

Figure 2. Nonmetric multidimensional scaling (NMDS) of the overall bacterial community composition according to Bray-Curtis distance matrices in mine tailings.

$0.06{ }^{13} \mathrm{C}$ atom \%) and $\mathrm{SM}_{-} \mathrm{FeS}_{2}\left(1.76 \pm 0.06{ }^{13} \mathrm{C}\right.$ atom \%) were higher than those in the controls YM_ck (1.12 \pm $0.01{ }^{13} \mathrm{C}$ atom \%) and SM_ck $\left(1.11 \pm 0.01{ }^{13} \mathrm{C}\right.$ atom \%). This result shows that fixation of ${ }^{13} \mathrm{C}_{-}-\mathrm{CO}_{2}$ occurred in these mine tailings with the addition of pyrite; the $\mathrm{CO}_{2}$-fixing capacities of autotrophs under $\mathrm{FeS}_{2}$ addition were 9.50土 $0.91 \mathrm{mg} \mathrm{kg}^{-1} \mathrm{~d}^{-1}$ in $\mathrm{YM}$ and $3.69 \pm 0.11 \mathrm{mg} \mathrm{kg}^{-1} \mathrm{~d}^{-1}$ in SM. 
(a)

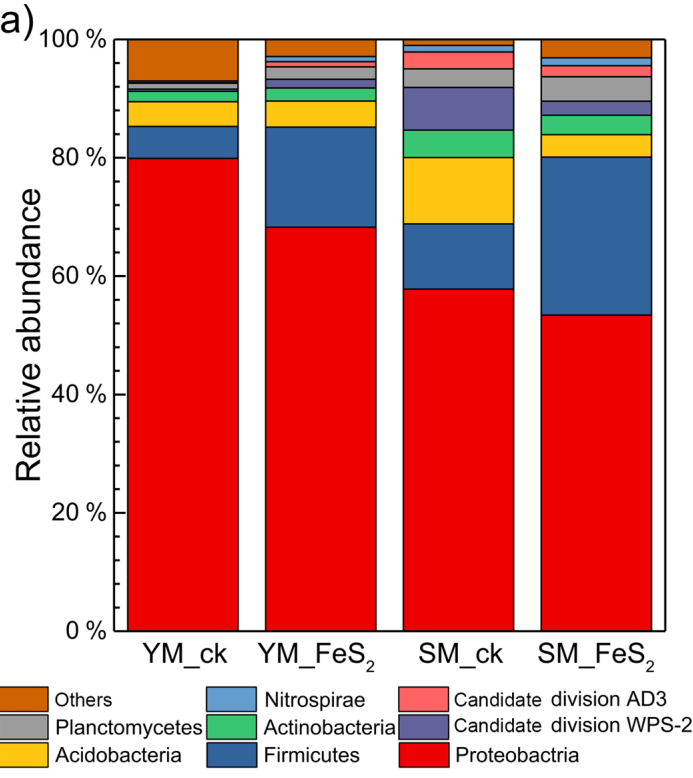

(b)

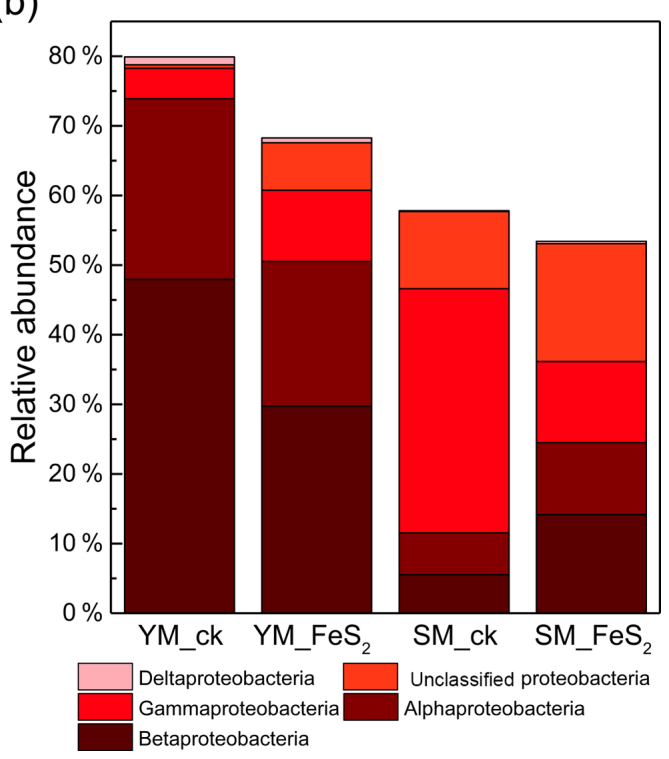

Figure 3. Relative abundances (percentages) of the main bacterial taxonomic groups identified, i.e., Proteobacteria, Firmicutes, Acidobacteria, Actinobacteria, candidate division WPS-2, Planctomycetes, candidate division AD3, and Nitrospirae (a), and classes Alphaproteobacteria, Betaproteobacteria, Deltaproteobacteria, and Gammaproteobacteria (within the phylum Proteobacteria) (b). For each tailing sample, the relative abundances of the sequences assigned to a given taxonomic unit were calculated for each of three subsamples, and the average value was then used to represent the relative abundance of each tailing sample.

\subsection{Bacterial communities in mine tailings under $\mathrm{FeS}_{2}$ addition}

A total of 220877 usable sequences (mean 24541 , minimum 9362, maximum 28400 ) were obtained from total genomic DNA. The ordering of samples by NMDS according to their OTU composition and Bray-Curtis dissimilarity measures (Fig. 2) demonstrated separation of the bacterial community structure in both YM and SM samples.

In this study, eight dominant bacterial phyla or candidate divisions (relative abundance $>1 \%$ ) and four proteobacterial classes were identified in the two mine tailings, including Proteobacteria (mainly composed of classes Alphaproteobacteria, Betaproteobacteria, Gammaproteobacteria, and Deltaproteobacteria), Firmicutes, Acidobacteria, Actinobacteria, candidate division WPS-2, Planctomycetes, candidate division AD3, and Nitrospirae (Fig. 3). In the YM tailings, pyrite addition significantly increased the relative abundances of candidate division AD3, Nitrospirae, and unclassified Proteobacteria by $0.75 \%(P=0.008), 0.59 \%$ $(P=0.019)$, and $6.33 \%(P<0.001)$, respectively. Similarly, $\mathrm{FeS}_{2}$ addition to $\mathrm{SM}$ tailings significantly increased the relative abundances of Firmicutes, Planctomycetes, unclassified Proteobacteria, Alphaproteobacteria, Betaproteobacteria, and Deltaproteobacteria by $15.69 \%(P<0.001)$, $0.97 \% \quad(P<0.001), 5.88 \% \quad(P=0.002), 4.35 \% \quad(P=$ $0.001), 8.61 \%(P<0.001)$, and $0.21 \%(P=0.003)$, respectively. However, the percentages of candidate division AD3, Acidobacteria, Actinobacteria, and Gammaproteobac- teria in SM by $0.97 \%(P=0.002), 7.43 \%(P=0.002)$, $1.35 \%(P=0.016)$, and $4.85 \%(P=0.002)$ decreased in the SM tailings with pyrite addition.

The total number of genera assigned to known taxa accounted for $29.89 \%$ of the total bacterial communities. In addition, we constructed a heat map diagram (Fig. 4) that shows the top 51 dominant genera with relative abundances above $0.02 \%$ in the mine tailings, accounting for $29.16 \%$ of the total bacterial communities. Specifically, Sulfobacillus $(8.04 \%)$ and Novosphingobium $(8.60 \%)$ accounted for $16.64 \%$ of the total bacterial communities and were the dominant taxa in the mine tailings. In contrast, autotrophic bacteria including Rhodanobacter $(0.04 \%)$, Pseudomonas (0.02\%), Acidithiobacillus (0.02\%), Thiobacillus $(0.04 \%)$, Ralstonia (0.02\%), Thiomonas (0.04\%), Burkholderia (0.09\%), Acidiphilium (1.49\%), Rhodobacter $(0.04 \%)$, Rhodoplanes $(0.59 \%)$, Nitrospira (0.02\%), Leptospirillum (0.80\%), Sulfobacillus (8.04\%), Clostridium $(0.04 \%)$, and Corynebacterium $(0.04 \%)$ accounted for $11.33 \%$ of the total bacterial communities. Whereby, Thiobacillus, Acidiphilium, Leptospirillum, Acidithiobacillus, and Sulfobacillus are ferrous and sulfur-oxidizing bacteria. For the YM tailings, pyrite addition significantly increased the relative abundances of the autotrophic genera Acidithiobacillus, Leptospirillum, Sulfobacillus, and Acidiphilium by $0.02 \%(P=0.001), 0.74 \%(P=0.002)$, $8.86 \%(P=0.043)$, and $1.57 \%(P<0.001)$, respectively. $\mathrm{FeS}_{2}$ addition also significantly increased the relative abundances of autotrophic genera in the SM tailings: Rho- 


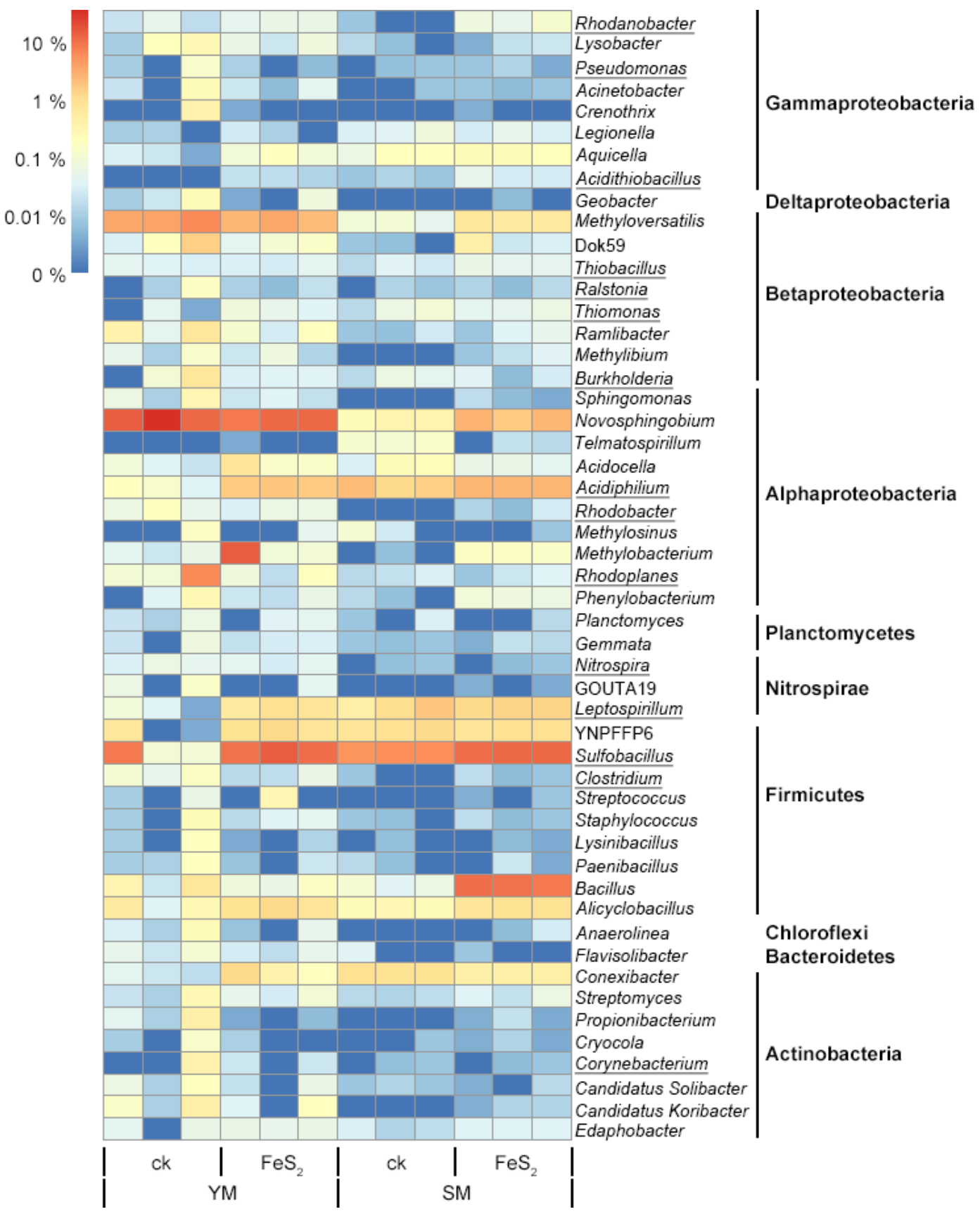

Figure 4. Heat map of the top genera with relative abundances above $0.02 \%$ in mine tailings. Autotrophic bacteria were marked with underlining.

danobacter, Acidithiobacillus, Thiobacillus, and Sulfobacillus by $0.07 \%(P=0.016), 0.03 \%(P=0.034), 0.02 \%$ $(P=0.030)$, and $5.99 \%(P<0.001)$, respectively.

\subsection{DNA SIP identification of autotrophs in mine tailings}

For quantitative analysis of $c b b L$ and $c b b M$ gene abundances, the buoyant densities of the DNA in isopycnic centrifugation gradients were employed to assess the labeling efficiencies of $c b b L$ or $c b b M$ gene-carrying carbon fixers in the DNA SIP microcosms (Fig. 5). $c b b L$ and $c b b M$ gene levels under ${ }^{13} \mathrm{C}$ $\mathrm{CO}_{2}$ treatment peaked at a density of $1.72 \mathrm{~g} \mathrm{~mL}^{-1}$ in both the ${ }^{12} \mathrm{C}-\mathrm{CO}_{2}$ and ${ }^{13} \mathrm{C}-\mathrm{CO}_{2}$ treatments. In addition, a shift toward heavy fractions was observed for $c b b L$ and $c b b M$ gene abundances in the ${ }^{13} \mathrm{C}_{-} \mathrm{CO}_{2}$ treatment (Fig. 5), with buoyant densities of $1.738 \mathrm{~g} \mathrm{~mL}^{-1}$ in $\mathrm{YM}_{-} \mathrm{FeS}_{2}$ and $1.734 \mathrm{~g} \mathrm{~mL}^{-1}$ in SM_FeS 2 . In contrast, the highest copy numbers of $c b b L$ and 
Ratio of maximum quantities based on qPCR

(cbbL gene)

$\begin{array}{llllllll}0.0 & 0.4 & 0.8 & 1.2 & 0.0 & 0.4 & 0.8 & 1.2\end{array}$

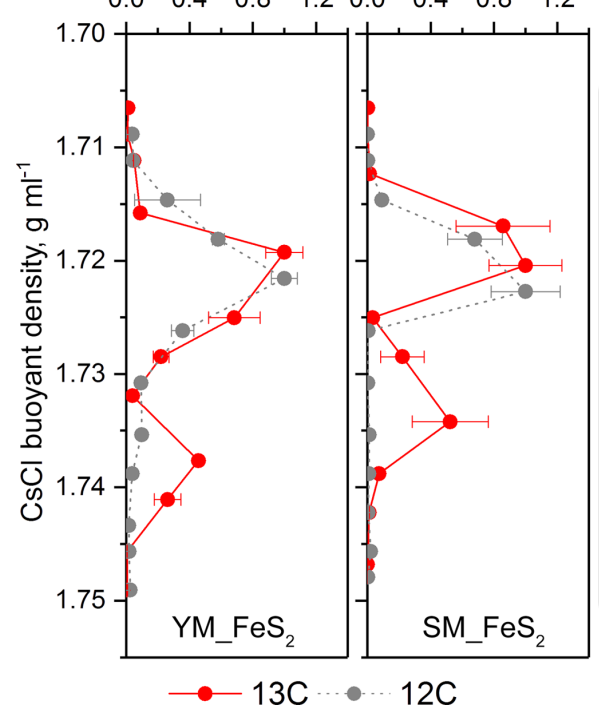

(cbbM gene)

$\begin{array}{llllllll}0.0 & 0.4 & 0.8 & 1.2 & 0.0 & 0.4 & 0.8 & 1.2\end{array}$

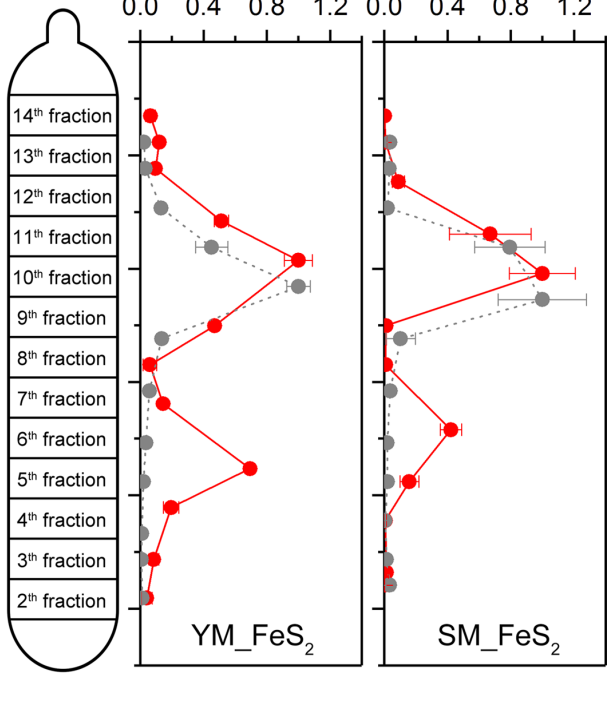

Figure 5. Quantitative distribution of $c b b L$ and $c b b M$ gene fragments across the entire buoyant density gradients of the DNA fractions from microcosms treated with $\mathrm{FeS}_{2}$ and incubated with ${ }^{12} \mathrm{C}-\mathrm{CO}_{2}$ or ${ }^{13} \mathrm{C}-\mathrm{CO}_{2}$. The normalized data consist of the ratio of the gene copy number for each DNA gradient to the maximum quantity for each treatment. The error bars represent the standard errors of triplicate microcosms, and each consisted of three technical replicates. $c b b L$ and $c b b M$ gene abundance qPCR data are presented in the Supplement.

$c b b M$ genes under the ${ }^{12} \mathrm{C}-\mathrm{CO}_{2}$ treatment appeared in the light fraction, with a buoyant density of $1.722-1.723 \mathrm{~g} \mathrm{~mL}^{-1}$.

$c b b L$ and $c b b M$ sequences, encoding the large subunit of RuBisCO, from the clone libraries in the ${ }^{13} \mathrm{C}$-DNA heavy fraction treated with ${ }^{13} \mathrm{C}-\mathrm{CO}_{2}$ were used for phylogenetic analysis (Fig. 6). The gene copy numbers of $c b b L$ were 16.50 -fold and 8.20-fold greater than those of $c b b M$ in the heavy fractions of $\mathrm{YM}_{-} \mathrm{FeS}_{2}$ and $\mathrm{SM}_{-} \mathrm{FeS}_{2}$, respectively. In addition, a vast majority of $c b b L$ and $c b b M$ gene sequences appear to be associated with unknown groups, with the exception of cbbL-OTU1, cbbL-OTU6, cbbL-OTU9, cbbMOTU5, and cbbM-OTU6. According to phylogenetic analysis based on amino acid sequences, the $c b b L$ gene OTUs are related to Sulfobacillus, Acidithiobacillus, and Azospirillum and the cbbM gene OTUs are related to Acidithiobacillus and Thiobacillus. The Sulfobacillus-like $c b b L$ gene sequence cbbL-OTU1 accounted for $30.11 \%$ and $34.74 \%$ of the total $c b b L$ gene sequences in the heavy fractions of $\mathrm{YM}_{-} \mathrm{FeS}_{2}$ and $\mathrm{SM}_{-} \mathrm{FeS}_{2}$, respectively. Conversely, Acidithiobacilluslike $c b b L$ and $c b b M$ genes accounted for only $2.15 \%$ and $4.21 \%$ of the total $c b b L$ gene sequences and $3.30 \%$ and $4.35 \%$ of the total $c b b M$ gene sequences in the heavy fractions of $\mathrm{YM}_{-} \mathrm{FeS}_{2}$ and $\mathrm{SM}_{-} \mathrm{FeS}_{2}$, respectively. In addition, the genus Sulfobacillus exhibited the highest relative abundance based on 16S rRNA analysis (Table S2), accounting for $17.18 \%$ and $18.24 \%$ of the heavy fractions of YM_FeS and $\mathrm{SM}_{-} \mathrm{FeS}_{2}$, respectively. The Leptospirillum genus accounted for $1.32 \%$ and $1.58 \%$ of the heavy fractions of
YM_FeS 2 and SM_FeS 2 , respectively, and Acidithiobacillus accounted for $0.11 \%$ and $0.06 \%$ in the heavy fractions of $\mathrm{YM}_{-} \mathrm{FeS}_{2}$ and $\mathrm{SM} \_\mathrm{FeS} 2$, respectively.

\section{Discussion}

\subsection{The effect of $\mathrm{FeS}_{2}$ on the entire bacterial community in mine tailings}

Acidic polymetallic mine tailings have strong potential for pyrite oxidation. In this study, a large amount of sulfuric acid was generated (increases of approximately 19.95 and $14.64 \mathrm{mg} \mathrm{g}^{-1}$ in $\mathrm{YM}_{-} \mathrm{FeS}_{2}$ and $\mathrm{SM}_{-} \mathrm{FeS}_{2}$, respectively), with a persistent decline in $\mathrm{pH}$ (decreases by 0.44 and 0.35 in $\mathrm{YM}_{-} \mathrm{FeS}_{2}$ and $\mathrm{SM} \mathrm{FeS}_{2}$, respectively), in only 14 days. These changes clearly indicate the oxidization of pyrite (i.e., acidification) in these mine tailings. Previous studies have found significant increases in certain bacterial phyla, such as Firmicutes and Nitrospirae (Chen et al., 2013; Liu et al., 2014), with the acidification process of mine tailings. In the present study, the bacterial composition in the different mine tailings varied greatly, with only Firmicutes increasing in both tested mine tailings under pyrite addition. This group might participate in the oxidization of sulfide minerals (Chen et al., 2013), and Sulfobacillus accounted for the majority of Firmicutes. However, many other microorganisms might be inhibited under pyrite addition. Korehi et al. (2014) and Liu et al. (2014) also indicated that the ongoing oxidation 


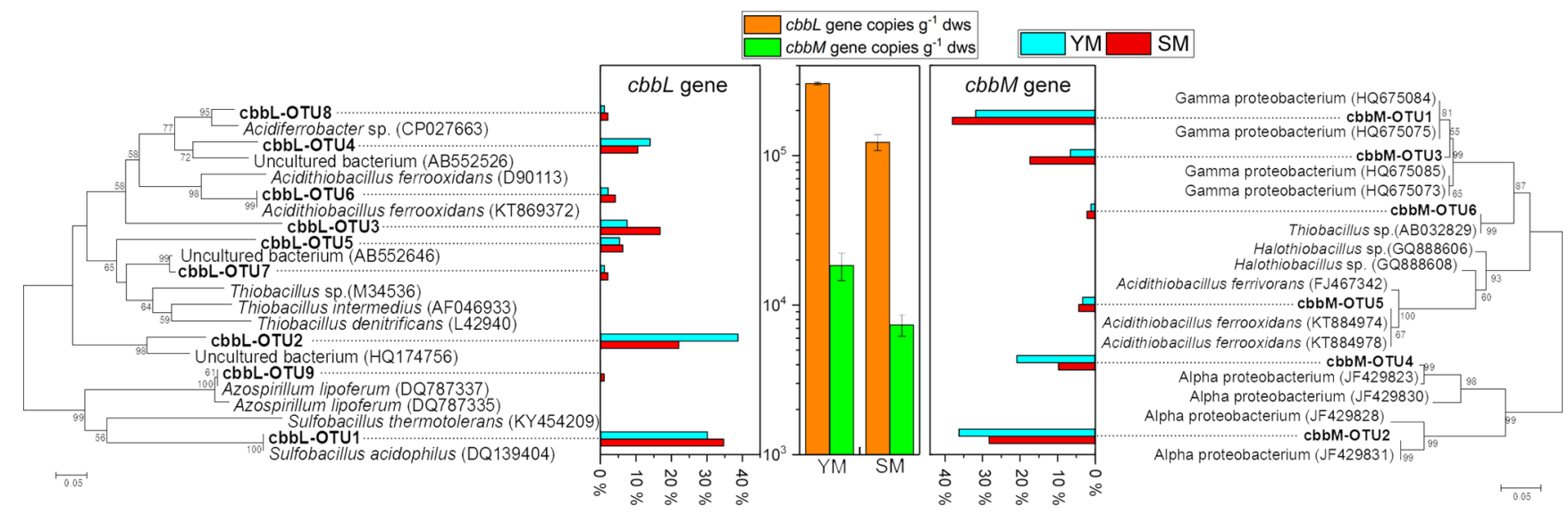

Figure 6. Phylogenetic tree of translated $c b b L$ and $c b b M$ sequences in the heavy fractions from YM and SM treated with FeS 2 . Relative frequencies (\%) are marked in the bar graph. Bootstrap values of $>50 \%$ are indicated at branch points. $c b b L$ and $c b b M$ gene copy numbers in the heavy fractions from $\mathrm{FeS}_{2}$-treated YM and SM are shown in the middle of the figure. The cultured genera most related to OTUs from $c b b L$ and $c b b M$ clone libraries are shown in Table $\mathrm{S} 1$.

process in mine tailings was accompanied by an increase in Firmicutes and a decrease in Actinobacteria as well as all classes of Proteobacteria except Gammaproteobacteria. In addition, Chen et al. (2013) and Liu et al. (2014) reported relative abundances of Euryarchaeota belonging to archaea significantly increased with decreasing $\mathrm{pH}$, which indicates that this taxon is an indicator of metal contamination (Hur et al., 2011). Euryarchaeota compete with Betaproteobacteria for ecological niches under such acidic conditions (Liu et al., 2014). However, in this study archaea have been ignored, which will require further study.

The growth of microorganisms in bare mine tailings is usually limited by the availability of organic carbon (Schimel and Weintraub, 2003). In our study, pyrite oxidization in mine tailings further increased the acidity of the mine tailings (pH decreased to 2.77 and 2.57 in $\mathrm{YM}_{-} \mathrm{FeS}_{2}$ and $\mathrm{SM}_{-} \mathrm{FeS}_{2}$, respectively). As a result, only microorganisms that were able to overcome resistance to infertility and/or acidophilic conditions maintained high activities. The level of some specific taxa, including the autotrophic genera Acidithiobacillus and Sulfobacillus, increased in both of the tested mine tailings under pyrite addition (Fig. 4), indicating high consistency of dominant autotrophic bacterial genera in different mine tailings. It is possible that acidophilic and/or autotrophic bacteria might be stimulated under conditions of pyrite oxidization and the availability of organic carbon (Deng et al., 2016; Antonelli et al., 2018); moreover, the main carbon fixers in these two mine tailings may be derived from the same groups. In addition, levels of major ferrous and sulfur-oxidizing genera, autotrophic Leptospirillum and Acidiphilium in $\mathrm{YM}_{-} \mathrm{FeS}_{2}$ and autotrophic Thiobacillus in $\mathrm{SM}_{-} \mathrm{FeS}_{2}$, were enhanced, suggesting the synchronization of pyrite oxidization and carbon sequestration in mine tailings.

\subsection{The effect of $\mathrm{FeS}_{2}$ on bacterial carbon sequestration in mine tailings}

Previous studies have shown that mine tailings provide an excellent substrate for carbon sequestration through the formation of carbonate due to the large surface area of the material grains (McCutcheon et al., 2016). Compared to soils and natural bedrock, mine tailings may exhibit higher carbonate precipitation rates (Wilson et al., 2009). Although the results showed that TOC content in mine tailings increased slightly under $\mathrm{FeS}_{2}$ addition, the soil acidification pretreatment and the addition of $20 \% \mathrm{FeS}_{2}$ in samples could increase the error of TOC analysis and calculation. And a longterm field test should be used to calculate the TOC increment in the acidification process of mine tailings in the future. Even so, in this study, the ${ }^{13} \mathrm{C}$ content in mine tailings increased significantly (Fig. 1). DNA SIP analysis demonstrated assimilation of a considerable amount of ${ }^{13} \mathrm{C}_{-} \mathrm{CO}_{2}$ by carbon fixers in the ${ }^{13} \mathrm{C}-\mathrm{CO}_{2}$-labeled mine tailing samples, leading to a significant shift in $c b b L$ or $c b b M$ gene-carrying genomic DNA into the heavy fraction. In addition, a peak at a buoyant density of $1.72 \mathrm{~g} \mathrm{~mL}^{-1}$ in ${ }^{13} \mathrm{C}_{-} \mathrm{CO}_{2}$-labeled mine tailing samples was observed, with a density lower than the peak in the ${ }^{12} \mathrm{C}-\mathrm{CO}_{2}$-labeled control experiment (see Supplement); the intensity of the ${ }^{13} \mathrm{C}$ peak at a higher density of $1.738 \mathrm{~g} \mathrm{~mL}^{-1}$ was also much lower than the ${ }^{12} \mathrm{C}$ peak at a higher density of $1.72 \mathrm{~g} \mathrm{~mL}^{-1}$. This suggests that a large proportion of the autotrophic microorganisms detected in the mine tailing samples did not fix atmospheric carbon. All of these results indicate the contribution of special autotrophic bacteria to carbon sequestration in mine tailings. To the best of our present knowledge, this report is the first to investigate carbon sequestration by autotrophic groups in mine tailings based on isotope tracers and DNA SIP. Previous studies have found that microbial photosynthesis accelerates car- 
bonate mineral precipitation and further induces mineralization (McCutcheon et al., 2014, 2016). In the present study, however, the microcosms were not cultured in the presence of illumination, and as a result, chemoautotrophic microorganisms, particularly iron and/or sulfide oxidizers (such as Sulfobacillus), were the dominant carbon fixers. These results indicate that bacterial carbon sequestration is mainly attributable to chemoautotrophic bacteria in mine tailings during pyrite oxidization. Nonetheless, archaea may have higher activities in RuBisCO-mediated carbon metabolic pathways (Kono et al., 2017), which will require further study.

During pyrite oxidization in mine tailings, some acidophilic autotrophic microorganisms showed very high activity levels; for example, levels of Sulfobacillus and Leptospirillum, both of which are vital ferrous and sulfur oxidizers, increased significantly. Zhang et al. (2016) identified genes for the CBB pathway and rTCA, but no other $\mathrm{CO}_{2}$ fixation pathways, in a copper bioleaching microbial community. Regarding the present study, the Sulfobacilluslike $c b b L$ gene was the major carbon-fixing-associated gene found. Ňancucheo and Johnson (2012) reported that among acidophilic prokaryotes isolated from mine-impacted environments, the ability to metabolize glycerate-3-phosphate appeared to be restricted to Firmicutes (e.g., Sulfobacillus) and that the glycerate-3-phosphate present in all of these acidophiles might be due to the activity of RuBisCO (Ňncucheo and Johnson, 2012). Previous studies have confirmed the existence of Sulfobacillus in mine tailings (Coral et al., 2018; Yu et al., 2018), and members of this genus have the ability to oxidize or reduce Fe(III) and oxidize sulfur (Dold et al., 2005). This ability is important because by adhering to mineral surfaces and further enhancing sulfide mineral oxidation, Sulfobacillus likely leads to a high mineral dissolution rate (Becker et al., 2011; Li et al., 2016). Although none of the $c b b L$ or $c b b M$ genes identified in our study were highly homologous to genes in Leptospirillum, Marín et al. (2017) reported that rTCA carbon fixation pathway genes were mainly found in Leptospirillum spp. RuBisCO is the most prominent enzyme, and the genes encoding the large subunit of RuBisCO serve as a marker for the analysis of autotrophic organisms, including bacteria, using the CBB cycle (Berg, 2011). The Sulfobacillus-like cbbL gene dominated the ${ }^{13} \mathrm{C}$-labeled DNA among carbon-fixing taxa, and the higher relative abundance of Sulfobacillus than Leptospirillum, according to $16 \mathrm{~S}$ rRNA analysis, demonstrates the contribution of the Sulfobacillus-like $c b b L$ gene to carbon sequestration. Regardless, although the number (or relative abundance) of autotrophs demonstrated their ability to sequester carbon, it did not reflect their ability to perform or their importance to ferrous and sulfur oxidation. For example, the limited percentage of Acidithiobacillus in the two mine tailings did not reflect the contribution of this genus to the oxidation of iron and sulfur. Falagán et al. (2017) highlighted the importance of thermotolerant acidophiles, such as Acidithiobacillus and Sulfobacillus, in extracting and re- covering metals from mine tailings. Furthermore, it has been known for many years that Acidithiobacillus can obtain energy by catalyzing oxidation of $\mathrm{Fe}^{2+}$ to $\mathrm{Fe}^{3+}$ from sulfites (Dold, 2014), which may significantly accelerate the rate of ferrous oxidization. The decreased level of total carbon, including low-molecular-weight carboxylic acids, may also limit the activity of this taxon (Dold et al., 2005).

In conclusion, this study is the first to elucidate carbon sequestration by autotrophic groups in the mine tailing acidification process based on isotope tracers and DNA SIP. Our results reveal higher ${ }^{13} \mathrm{C}$ atom $\%$ values with the addition of pyrite than in controls after a 14-day incubation. The Sulfobacillus genus was dominant in the pyrite-treated bacterial communities and was also the primary carbon fixer carrying the $c b b L$ gene. Overall, the $c b b L$ gene may play a vital role in carbon sequestration in the sulfide mineral oxidation of mine tailings.

Data availability. The data are available from the first author and corresponding author upon request.

Supplement. The supplement related to this article is available online at: https://doi.org/10.5194/bg-16-573-2019-supplement.

Author contributions. YL, XD, and ZJ led the design of the study, assisted by QS. All sample collection and analyses were performed by YL, ZW, ZX, QZ, and HS. YL wrote the paper with contributions from ZW.

Competing interests. The authors declare that they have no conflict of interest.

Acknowledgements. This study was funded by the National Natural Science Foundation of China (31800456), the National Key Basic Research Program of China (2015CB150506), the Strategic Priority Research Program of the CAS (XDB15040000), the Natural Science Foundation of the Anhui Provincial Education Department (KJ2018A0032), and the PhD Research Startup Foundation of Anhui University (J01003269).

Edited by: Luo Yu

Reviewed by: Weidong Kong and one anonymous referee

\section{References}

Alfreider, A., Baumer, A., Bogensperger, T., Posch, T., Salcher, M. M., and Summerer, M.: $\mathrm{CO}_{2}$ assimilation strategies in stratified lakes: Diversity and distribution patterns of chemolithoautotrophs, Environ. Microbiol., 19, 2754-2768, https://doi.org/10.1111/1462-2920.13786, 2017. 
Antonelli, P. M., Fraser, L. H., Gardner, W. C., Broersma, K., Karakatsoulis, J., and Phillips, M. E.: Long term carbon sequestration potential of biosolids-amended copper and molybdenum mine tailings following mine site reclamation, Ecol. Eng., 117, 38-49, https://doi.org/10.1016/j.ecoleng.2018.04.001, 2018.

Becker, T., Gorham, N., Shiers, D. W., and Watling, H. R.: In situ imaging of Sulfobacillus thermosulfidooxidans on pyrite under conditions of variable $\mathrm{pH}$ using tapping mode atomic force microscopy, Process. Biochem., 46, 966-976, https://doi.org/10.1016/j.procbio.2011.01.014, 2011.

Berg, I. A.: Ecological aspects of the distribution of different autotrophic $\mathrm{CO}_{2}$ fixation pathways, Appl. Environ. Microbiol., 77, 1925-1936, https://doi.org/10.1128/aem.02473-10, 2011.

Campbell, B. J. and Cary, S. C.: Abundance of reverse tricarboxylic acid cycle genes in free-living microorganisms at deep-sea hydrothermal vents, Appl. Environ. Microbiol., 70, 6282-6289, https://doi.org/10.1128/AEM.70.10.6282-6289.2004, 2004.

Chen, L., Li, J., Chen, Y., Huang, L., Hua, Z., Hu, M., and Shu, W.: Shifts in microbial community composition and function in the acidification of a lead/zinc mine tailings, Environ. Microbiol., 15, 2431-2444, https://doi.org/10.1111/1462-2920.12114, 2013.

Coral, T., Descostes, M., De Boissezon, H., Bernier-Latmani, R., de Alencastro, L. F., and Rossi, P.: Microbial communities associated with uranium in-situ recovery mining process are related to acid mine drainage assemblages, Sci. Total Environ., 628-629, 26-35, https://doi.org/10.1016/j.scitotenv.2018.01.321, 2018.

Deng, X., Zhan, Y., Wang, F., Ma, W., Ren, Z., Chen, X., Qin, F., Long, W., Zhu, Z., and Lv, X.: Soil organic carbon of an intensively reclaimed region in China: Current status and carbon sequestration potential, Sci. Total Environ., 565, 539-546, https://doi.org/10.1016/j.scitotenv.2016.05.042, 2016.

Dold, B.: Evolution of acid mine drainage formation in sulphidic mine tailings, Minerals, 4, 621-641, 2014.

Dold, B., Blowes, D. W., Dickhout, R., Spangenberg, J. E., and Pfeifer, H.-R.: Low molecular weight carboxylic acids in oxidizing porphyry copper tailings, Environ. Sci. Technol., 39, 25152521, https://doi.org/10.1021/es040082h, 2005.

Falagán, C., Grail, B. M., and Johnson, D. B.: New approaches for extracting and recovering metals from mine tailings, Miner. Eng., 106, 71-78, https://doi.org/10.1016/j.mineng.2016.10.008, 2017.

Harrison, A. L., Power, I. M., and Dipple, G. M.: Accelerated carbonation of brucite in mine tailings for carbon sequestration, Environ. Sci. Technol., 47, 126-134, https://doi.org/10.1021/es3012854, 2013.

Heron, G., Crouzet, C., Bourg, A. C. M., and Christensen, T. H.: Speciation of $\mathrm{Fe}(\mathrm{II})$ and $\mathrm{Fe}(\mathrm{III})$ in contaminated aquifer sediments using chemical extraction techniques, Environ. Sci. Technol., 28, 1698-1705, https://doi.org/10.1021/es00058a023, 1994.

Hu, Y., Mgelwa Abubakari, S., Singh Anand, N., and Zeng, D.: Differential responses of the soil nutrient status, biomass production, and nutrient uptake for three plant species to organic amendments of placer gold mine-tailing soils, Land Degrad. Dev., 29, 2836-2845, https://doi.org/10.1002/ldr.3002, 2018.

Hur, M., Kim, Y., Song, H.-R., Kim, J. M., Choi, Y. I., and Yi, H.: Effect of genetically modified poplars on soil microbial communities during the phytoremediation of waste mine tailings, Appl. Environ. Microbiol., 77, 7611-7619, https://doi.org/10.1128/aem.06102-11, 2011.
Kono, T., Mehrotra, S., Endo, C., Kizu, N., Matusda, M., Kimura, H., Mizohata, E., Inoue, T., Hasunuma, T., Yokota, A., Matsumura, H., and Ashida, H.: A RuBisCO-mediated carbon metabolic pathway in methanogenic archaea, Nat. Comm., 8, 14007, https://doi.org/10.1038/ncomms14007, 2017.

Korehi, H., Blöthe, M., and Schippers, A.: Microbial diversity at the moderate acidic stage in three different sulfidic mine tailings dumps generating acid mine drainage, Res. Microbiol., 165, 713-718, https://doi.org/10.1016/j.resmic.2014.08.007, 2014.

Li, Q., Sand, W., and Zhang, R.: Enhancement of biofilm formation on pyrite by Sulfobacillus thermosulfidooxidans, Minerals, 6, e71, https://doi.org/10.3390/min6030071, 2016.

Li, X., Bond, P. L., Van Nostrand, J. D., Zhou, J., and Huang, L.: From lithotroph- to organotroph-dominant: Directional shift of microbial community in sulphidic tailings during phytostabilization, Sci. Rep., 5, 12978, https://doi.org/10.1038/srep12978, 2015.

Li, Y., Sun, Q., Zhan, J., Yang, Y., and Wang, D.: Soil-covered strategy for ecological restoration alters the bacterial community structure and predictive energy metabolic functions in mine tailings profiles, Appl. Microbiol. Biot., 101, 2549-2561, https://doi.org/10.1007/s00253-016-7969-7, 2017.

Liu, J., Hua, Z., Chen, L., Kuang, J., Li, S., Shu, W., and Huang, L.: Correlating microbial diversity patterns with geochemistry in an extreme and heterogeneous environment of mine tailings, Appl. Environ. Microbiol., 80, 3677-3686, https://doi.org/10.1128/aem.00294-14, 2014.

Lottermoser, B. G.: Mine wastes: characterization, treatment and environmental impacts, Springer, New York, 2010.

Marín, S., Acosta, M., Galleguillos, P., Chibwana, C., Strauss, H., and Demergasso, C.: Is the growth of microorganisms limited by carbon availability during chalcopyrite bioleaching?, Hydrometallurgy, 168, 13-20, https://doi.org/10.1016/j.hydromet.2016.10.003, 2017.

McCutcheon, J., Power, I. M., Harrison, A. L., Dipple, G. M., and Southam, G.: A greenhouse-scale photosynthetic microbial bioreactor for carbon sequestration in magnesium carbonate minerals, Environ. Sci. Technol., 48, 9142-9151, https://doi.org/10.1021/es500344s, 2014.

McCutcheon, J., Wilson, S. A., and Southam, G.: Microbially accelerated carbonate mineral precipitation as a strategy for in situ carbon sequestration and rehabilitation of asbestos mine sites, Environ. Sci. Technol., 50, 1419-1427, https://doi.org/10.1021/acs.est.5b04293, 2016.

Meyer, N. A., Vögeli, J. U., Becker, M., Broadhurst, J. L., Reid, D. L., and Franzidis, J. P.: Mineral carbonation of PGM mine tailings for $\mathrm{CO}_{2}$ storage in South Africa: A case study, Miner. Eng., 59, 45-51, https://doi.org/10.1016/j.mineng.2013.10.014, 2014.

Nanba, K., King, G. M., and Dunfield, K.: Analysis of facultative lithotroph distribution and diversity on volcanic deposits by use of the large subunit of ribulose 1,5-bisphosphate carboxylase/oxygenase, Appl. Environ. Microbiol., 70, 2245-2253, https://doi.org/10.1128/aem.70.4.2245-2253.2004, 2004.

Ňancucheo, I. and Johnson, D. B.: Acidophilic algae isolated from mine-impacted environments and their roles in sustaining heterotrophic acidophiles, Front. Microbiol., 3, e325, https://doi.org/10.3389/fmicb.2012.00325, 2012. 
Raven, J. A.: Rubisco: still the most abundant protein of Earth?, New Phytol., 198, 1-3, 2013.

Schimel, J. P. and Weintraub, M. N.: The implications of exoenzyme activity on microbial carbon and nitrogen limitation in soil: a theoretical model, Soil Biol. Biochem., 35, 549-563, https://doi.org/10.1016/s0038-0717(03)00015-4, 2003.

Tabita, F. R.: Microbial ribulose 1,5-bisphosphate carboxylase/oxygenase: A different perspective, Photosynth. Res., 60, 128, https://doi.org/10.1023/a:1006211417981, 1999.

Tabita, R. S., Sriram, Hanson, T. E., Kreel, N. E., and Scott, S. S.: Distinct form I, II, III, and IV Rubisco proteins from the three kingdoms of life provide clues about Rubisco evolution and structure/function relationships, J. Exp. Bot., 59, 1515-1524, 2008.

Wang, G., Welham, C., Feng, C., Chen, L., and Cao, F.: Enhanced soil carbon storage under agroforestry and afforestation in subtropical China, Forests, 6, 2307-2323, 2015.

White, A., Cannell, M. G. R., and Friend, A. D.: $\mathrm{CO}_{2}$ stabilization, climate change and the terrestrial carbon sink, Global change biology, Glob. Change Biol., 6, 817-833, https://doi.org/10.1046/j.1365-2486.2000.00358.x, 2000.

Wilson, S. A., Dipple, G. M., Power, I. M., Thom, J. M., Anderson, R. G., Raudsepp, M., Gabites, J. E., and Southam, G.: Carbon dioxide fixation within mine wastes of ultramafic-hosted ore deposits: Examples from the Clinton Creek and Cassiar chrysotile deposits, Canada, Econ. Geol., 104, 95-112, 2009.
Yin, G., and Catalan, L. J.: Use of alkaline extraction to quantify sulfate concentration in oxidized mine tailings, J. Environ. Qual., 32, 2410-2413, 2003.

Young, I., Renault, S., and Markham, J.: Low levels organic amendments improve fertility and plant cover on nonacid generating gold mine tailings, Ecol. Eng., 74, 250-257, https://doi.org/10.1016/j.ecoleng.2014.10.026, 2015.

Yu, R., Hou, C., Liu, A., Peng, T., Xia, M., Wu, X., Shen, L., Liu, Y., Li, J., Yang, F., Qiu, G., Chen, M., and Zeng, W.: Extracellular DNA enhances the adsorption of Sulfobacillus thermosulfidooxidans strain ST on chalcopyrite surface, Hydrometallurgy, 176, 97-103, https://doi.org/10.1016/j.hydromet.2018.01.018, 2018.

Zhang, X., Niu, J., Liang, Y., Liu, X., and Yin, H.: Metagenomescale analysis yields insights into the structure and function of microbial communities in a copper bioleaching heap, BMC Genetics, 17, 21 pp., https://doi.org/10.1186/s12863-016-0330-4, 2016.

Zheng, Y., Huang, R., Wang, B. Z., Bodelier, P. L. E., and Jia, Z. J.: Competitive interactions between methaneand ammonia-oxidizing bacteria modulate carbon and nitrogen cycling in paddy soil, Biogeosciences, 11, 3353-3368, https://doi.org/10.5194/bg-11-3353-2014, 2014.

Zhou, J., Wu, L., Deng, Y., Zhi, X., Jiang, Y.-H., Tu, Q., Xie, J., Van Nostrand, J. D., He, Z., and Yang, Y.: Reproducibility and quantitation of amplicon sequencing-based detection, ISME J., 5, 1303-1313, https://doi.org/10.1038/ismej.2011.11, 2011. 